\title{
Characterization and Low-Resolution Structure of an Extremely Thermostable Esterase of Potential Biotechnological Interest from Pyrococcus furiosus
}

\author{
F. Mandelli ${ }^{1}$ T. A. Gonçalves ${ }^{1,2}$ - C. A. Gandin ${ }^{3}$ A. C. P. Oliveira ${ }^{1,2} \cdot$ \\ M. Oliveira Neto $^{3} \cdot$ F. M. Squina ${ }^{1}$
}

Published online: 24 September 2016

(C) Springer Science+Business Media New York 2016

\begin{abstract}
Enzymes isolated from extremophiles often exhibit superior performance and potential industrial applications. There are several advantages performing biocatalysis at elevated temperatures, including enhanced reaction rates, increased substrate solubility and decreased risks of contamination. Furthermore, thermophilic enzymes usually exhibit high resistance against many organic solvents and detergents, and are also more resistant to proteolytic attack. In this study, we subcloned and characterized an esterase from the hyperthermophilic archaeon Pyrococcus furiosus (Pf_Est) that exhibits optimal activity around $80^{\circ} \mathrm{C}$ using naphthol-derived substrates and $p$-nitrophenyl palmitate $(p \mathrm{NPP})$. According to the circular dichroism spectra, the secondary structure of $P$. furiosus esterase, which is predominantly formed by a $\beta$-sheet structure, is very stable, even after incubation at $120^{\circ} \mathrm{C}$. We performed SAXS to determine the low-resolution structure of Pf_Est, which is monomeric in solution at $80{ }^{\circ} \mathrm{C}$ and has a molecular weight of $28 \mathrm{kDa}$. The $\mathrm{Km}$ and $V_{\max }$ values for
\end{abstract}

Electronic supplementary material The online version of this article (doi:10.1007/s12033-016-9975-5) contains supplementary material, which is available to authorized users.

F. M. Squina

fabio.squina@bioetanol.org.br

1 Laboratório Nacional de Ciência e Tecnologia do Bioetanol (CTBE), Centro Nacional de Pesquisa em Energia e Materiais (CNPEM), Rua Giuseppe Máximo Scolfaro, n 10000 , Campinas, SP 13083-970, Brazil

2 Departamento de Bioquímica, Instituto de Biologia (IB), Universidade Estadual de Campinas (UNICAMP), Campinas, SP, Brazil

3 Departamento de Física e Biofísica, Instituto de Biociências de Botucatu, UNESP Univ Estadual Paulista, Botucatu, SP, Brazil this esterase acting on $p$ NPP were $0.53 \mathrm{mmol} / \mathrm{L}$ and $6.5 \times 10^{-3} \mathrm{U}$, respectively. Pf_Est was most active in the immiscible solvents and retained more than $50 \%$ in miscible solvents. Moreover, Pf_Est possesses transesterification capacity, presenting better results when isobutanol was used as an acyl acceptor $\left(2.69 \pm 0.14 \times 10^{-2} \mu \mathrm{mol} /\right.$ min $\mathrm{mg}$ ) and the highest hydrolytic activity toward olive oil among different types of oils testes in this study. Collectively, these biophysical and catalytic properties are of interest for several biotechnological applications that require harsh conditions, including high temperature and the presence of organic solvents.

Keywords Hyperthermophilic - kinetics parameters . Transesterification $\cdot$ Circular dichroism $\cdot$ SAXS

\section{Introduction}

Lipases and esterases are lipolytic enzymes that make up an important group of enzymes which play a role in the metabolism of lipid degradation. Most of the lipases used in industry are of fungal and bacterial origin $[1,2]$.

Lipolytic enzymes are very attractive for industrial applications such as the detergent, oleochemical, pulp and paper industries, synthesis of flavor esters, and resolution of chiral drugs [3-6].

These enzymes can be used as catalysts to cleave ester bonds in aqueous media and in organic media, which can catalyze formation of ester bonds via esterification, interesterification, and transesterification reactions [7]. It was also stated that esterases degrade natural materials and industrial pollutants such as cereal wastes, plastics, and other toxic chemicals [8]. 
Thermophilic enzymes are known due to their higher stability against the denaturing action of heat and chemical denaturants when comparing to mesophilic enzymes. As a result, they can be used as biocatalysts under rather harsh environmental conditions [9].

The hyperthermophilic archaea Pyrococcus furiosus was first isolated by Fiala and Stetter [10] from a Vulcano Island near southern Italy. This hyperthermophilic archaeon is an obligate anaerobic heterotroph that grows optimally at $100{ }^{\circ} \mathrm{C}$. P. furiosus is also a source of several industrially important enzymes [11].

In this study, we report gene subcloning and expression, followed by purification, functional and biophysical characterization, along with low-resolution structure of an esterase from Pyrococcus furiosus (Pf_Est). Thus, the biochemical and biophysical characterization of Pf_Est reveals its potential to be used in biotechnological applications.

\section{Materials and Methods}

\section{Synthesis of the Esterase Coding Sequence}

In this study, we show a characterization of a hyperthermophilic esterase from Pyrococcus furiosus. The region of the gene AFN03900.1 (amino acids 160-404), predicted as an esterase was synthesized (GenOne BiotechnologiesRio de Janeiro, Brazil) by a solid-phase synthesis using phosphoramidite method [12] (Figure S1). The gene was synthesized based on the nucleotide sequence, delivered in the vector pBluescript II SK (Figure S2), and digested with the NheI and BamHI restriction enzymes and then inserted into the expression vector pET-28a. Sanger sequencing $(3500 \times$ L Genetic Analyzer, Thermo Scientific) was performed to check the sequence accuracy of the subcloned DNA fragment. The pET28a/Pf_Est plasmid was transformed in expression cell, as explained below.

\section{Protein Expression and Purification}

Escherichia coli BL21 (DE3) was transformed with the pET28a/Pf_Est plasmid and plated in selective solid LB medium containing kanamycin $(50 \mu \mathrm{g} / \mathrm{mg})$. Cells from a single colony were grown in $8 \mathrm{~mL}$ of liquid LB-kanamycin (at the same previous concentration) for $16 \mathrm{~h}$ at $37{ }^{\circ} \mathrm{C}$ and $250 \mathrm{rpm}$. After that, this culture was passed to $800 \mathrm{~mL}$ of fresh LB-kanamycin medium and grown under the same conditions until reaching an optical density of 0.6 at $600 \mathrm{~nm}$. Afterward, the recombinant protein expression was induced by adding $0.5 \mathrm{mmol} / \mathrm{L}$ IPTG. After $4 \mathrm{~h}$, the cells were harvested at $8500 \mathrm{~g}$ and stored at $-20{ }^{\circ} \mathrm{C}$. The cells were again suspended using lysis buffer $(20 \mathrm{mmol} / \mathrm{L}$ sodium phosphate $\mathrm{pH} 7.5,100 \mathrm{mmol} / \mathrm{L} \mathrm{NaCl}, 5 \mathrm{mmol} / \mathrm{L}$ imidazole, $80 \mu \mathrm{g} / \mathrm{mL}$ egg lysozyme, and $5 \mathrm{mmol} / \mathrm{L}$ PMSF), followed by mechanical cell disruption (Ultrasonic Processor, Sonics Vibracell). Finally, the extract was centrifuged at $10,000 \mathrm{~g}$ for $30 \mathrm{~min}$ at $4{ }^{\circ} \mathrm{C}$.

The Pf_Est was purified by chromatography using an ÄKTA FPLC system (GE Healthcare). The cell supernatant was loaded onto a $5 \mathrm{~mL}$ HiTrap Chelating HP column (GE Healthcare) charged with $\mathrm{Ni}^{2+}$ and pre-equilibrated with $20 \mathrm{mmol} / \mathrm{L}$ sodium phosphate $\mathrm{pH} 7.5,100 \mathrm{mmol} / \mathrm{L} \mathrm{NaCl}$, $5 \mathrm{mmol} / \mathrm{L}$ imidazole (buffer A) at $1 \mathrm{~mL} / \mathrm{min}$. The column was washed with 10 column volumes $(\mathrm{CVs})$ of buffer $\mathrm{A}$ to remove unbound fractions, and the enzyme fractions were eluted using a nonlinear, imidazole gradient from 5 to $500 \mathrm{mmol} / \mathrm{L}$ (buffer $\mathrm{B}-20 \mathrm{mmol} / \mathrm{L}$ sodium phosphate $\mathrm{pH}$ $7.5,100 \mathrm{mmol} / \mathrm{L} \mathrm{NaCl}$, and $500 \mathrm{mmol} / \mathrm{L}$ imidazole) in 20 CVs. The protein fractions were pooled and concentrated to $2 \mathrm{~mL}$ using a $10 \mathrm{kDa}$-pore Amicon, then a second purification step was performed using a Superdex 200 10/300 GL column (GE Healthcare), which was pre-equilibrated and eluted with $20 \mathrm{mmol} / \mathrm{L}$ sodium phosphate buffer $\mathrm{pH}$ 7.5 containing $100 \mathrm{mmol} / \mathrm{L} \mathrm{NaCl}$ at flow of $0.5 \mathrm{~mL} / \mathrm{min}$; elution was monitored at $280 \mathrm{~nm}$. Enzyme purification was analyzed by sodium dodecyl sulfate polyacrylamide gel (SDS-PAGE).

\section{Enzyme Activity Assays}

The esterase activity was assessed using the substrates $\alpha$ naphthyl acetate and $\alpha$-naphthyl butyrate according to the methods previously described [13]. Briefly, the enzymatic solution $(20 \mu \mathrm{L}$ at $0.5 \mathrm{mg} / \mathrm{mL})$ was mixed with $20 \mu \mathrm{L}$ of sodium acetate buffer $(100 \mathrm{mmol} / \mathrm{L}, \mathrm{pH} 5.5)$ and $10 \mu \mathrm{L}$ of substrate $(50 \mathrm{mmol} / \mathrm{L})$. The reaction was incubated at $80^{\circ} \mathrm{C}$ for $30 \mathrm{~min}$, then $50 \mu \mathrm{L}$ of fast garnet salt $(0.1 \% \mathrm{w} / \mathrm{v}$ and SDS $15 \% \mathrm{w} / \mathrm{v}$ in DMSO) was added and the absorbance was read at $560 \mathrm{~nm}$. Pf_Est was also assayed using $p$-nitrophenyl palmitate ( $p$ NPP, Sigma-Aldrich) as the substrate. The reaction was conducted by mixing $30 \mu \mathrm{L}$ of $p$ NPP (10 mmol/L in isopropanol), $110 \mu \mathrm{L}$ of the buffer (Tris $\mathrm{HCl} \mathrm{pH} 8.0+$ Arabic Gum $0.1 \% \mathrm{w} / \mathrm{v}+$ Triton $\mathrm{X} 1000.4 \% \mathrm{w} / \mathrm{v})$, and $10 \mu \mathrm{L}(0.5 \mathrm{mg} / \mathrm{mL})$ of the purified enzyme. The reaction was incubated at $80^{\circ} \mathrm{C}$ for $20 \mathrm{~min}$, and then the absorbance was read at $410 \mathrm{~nm}$ [14]. A control reaction was measured with the absence of the enzyme for both assays. The standard curves using 10 different concentrations of 1-Naphthol (Sigma-Aldrich) and 4-nitrophenol (Sigma-Aldrich) were used for the enzyme quantification assays. The equation obtained for adjustment of the 1-Naphthol curve was $y=71.922 \mathrm{x}+0.0123$ with $R^{2}=0.9966$ and for 4-nitrophenol was $y=61.41 \times$ with $R^{2}=0.9946$. One unit of esterase activity was defined as the amount of enzyme required to release $1 \mu \mathrm{mol}$ of 
product (4-nitrophenol (pNP) when the substrate utilized was the $p$ NPP and 1-naphthol when the substrates utilized were $\alpha$-naphthyl acetate and $\alpha$-naphthyl butyrate) per minute. To obtain the specific activity, this value was divided by the amount of protein utilized in each assay. All assays were performed in triplicate. The specific activities of purified enzyme for each purification step were evaluated.

\section{Determination of Optimum pH, Temperature, and Kinetic Parameters}

The optimum $\mathrm{pH}$ and $\mathrm{pH}$ stability were determined by measuring the enzymatic activity in different buffers at $100 \mathrm{mmol} / \mathrm{L}$ (glycine- $\mathrm{HCl} \mathrm{pH} 2.6$, citrate buffer $\mathrm{pH}$ 3.6-6.0, phosphate buffer $\mathrm{pH}$ 6.5-8.0, and glycine $\mathrm{NaOH}$ buffer $\mathrm{pH}$ 9.0-10.4). The optimum $\mathrm{pH}$ was estimated at $80{ }^{\circ} \mathrm{C}$ using three substrates: $\alpha$-naphthyl acetate, $\alpha$-naphthyl butyrate, and $p$ NPP. The $\mathrm{pH}$ stability was estimated by the incubation of Pf_Est for $30 \mathrm{~min}$ in the different pHs followed by the evaluation of the remaining activity by $p$ NPP assay.

The optimum temperature was estimated by measuring the relative enzyme activity, using $\alpha$-naphthyl acetate, $\alpha$ naphthyl butyrate, and $p$ NPP as substrates, at various temperatures $\left(55-100{ }^{\circ} \mathrm{C}\right)$ using $100 \mathrm{mmol} / \mathrm{L}$ sodium acetate buffer at $\mathrm{pH} 5.5$ (for assays with $\alpha$-naphthyl substrates) and $50 \mathrm{mmol} / \mathrm{L}$ Tris- $\mathrm{HCl} \mathrm{pH} 8.0$ (for assays with $p$ NPP). The temperature stability was performed by incubation of Pf_Est at $65,75,85$, and $120{ }^{\circ} \mathrm{C}$ until enzymes loses more than $50 \%$ of its activity. Afterward, the enzymatic activity was evaluated using $p$ NPP as substrates.

The stability analysis of Pf_Est in solvents was performed according to Sande et al. [15]. Briefly, the pure enzyme was incubated with two concentrations (5 and $50 \%$ v/v-solvent/Buffer Tris $\mathrm{HCl} \mathrm{pH} 8.0$ + Arabic Gum $0.1 \% \mathrm{w} / \mathrm{v}+$ TritonX $1000.4 \% \mathrm{w} / \mathrm{v}$ ) of water-miscible solvents (methanol, ethanol, 2-propanol, and isobutanol) and water-immiscible solvents ( $n$-hexane and dichloromethane) at $60{ }^{\circ} \mathrm{C}$ for $30 \mathrm{~min}$ and then the enzymatic activity was dosed using $p$ NPP.

Kinetic parameters were determined against $p$ NPP, where the substrate concentrations ranged from 0.05 to $6.0 \mathrm{mmol} / \mathrm{L}$. Km, $V_{\max }$, and kcat values were calculated using GraphPad Prisma 6.0 (GraphPad Software), based on the Michaelis-Menten enzyme kinetic model.

\section{Circular Dichroism Spectroscopy and Thermal Denaturation}

Circular dichroism spectroscopy and thermal denaturation were performed according to Mandelli et al. [16]. The farUV CD spectra were recorded, from 190 to $260 \mathrm{~nm}$, in a 1-mm quartz cuvette using a spectropolarimeter (Jasco J-810_Jasco International Co. Ltd., Japan), equipped with a Peltier temperature control unit. The purified enzyme $(0.2 \mathrm{mg} / \mathrm{mL})$ diluted in $75 \mathrm{mmol} / \mathrm{L}$ of sodium phosphate buffer, $\mathrm{pH} 7.5$, was used for collection of spectral data. For thermal scans, the protein samples $(0.2 \mathrm{mg} / \mathrm{mL})$ were heated from 20 to $100{ }^{\circ} \mathrm{C}$ and subsequently cooled to $20{ }^{\circ} \mathrm{C}$ with a heating/cooling rate of $1{ }^{\circ} \mathrm{C} / \mathrm{min}$, controlled by a Jasco programmable Peltier element. Moreover, the enzyme was heated at $120{ }^{\circ} \mathrm{C}$ for $15 \mathrm{~min}$ in an incubator (TE 393/2 - Tecnal, Brazil) and then the far-UV CD spectra were recorded.

\section{Small Angle X-ray Scattering}

Small angle X-ray scattering (SAXS) data were collected at the SAXS2 beamline at the Brazilian Synchrotron Light Laboratory (LNLS). The wavelength of the incident radiation was set to $\lambda=1.55 \AA$ and the X-ray patterns were recorded with a two-dimensional $\mathrm{CCD}$ detector. The sample detector distance was $1040.48 \mathrm{~mm}$, resulting in a scattering vector range of $0.016<q<0.313 \AA^{-1}$, where $q$ is the magnitude of the q-vector defined by $q=4 \pi \sin (\theta) / \lambda(2 \theta$ is the scattering angle). Data were collected at $80{ }^{\circ} \mathrm{C}$, which corresponds to the optimum temperature of the enzyme and in concentrations of $0.5,1$, and $5 \mathrm{mg} / \mathrm{mL}$ in $20 \mathrm{mmol} / \mathrm{L}$ phosphate buffer, $100 \mathrm{mmol} / \mathrm{L}$ $\mathrm{NaCl}$, and $\mathrm{pH}$ 7.5. The SAXS patterns were corrected for the detector response and scaled by the incident beam intensity and absorption of the samples. The background scattering curve was subtracted from the corresponding sample scattering. Integration of the SAXS patterns was performed using the Fit2D software [17]. SAXS data were analyzed according to Alvarez et al. [18]. Briefly, the programs used in SAXS analyses were GNOM software [19], SAXSmoW [20], GASBOR [21], CRYSOL [22], and SUPCOMB [21].

\section{Transesterification and Hydrolytic Activity}

The transesterification activity was measured according to Shih and Pan [14] with some modifications. Briefly, $0.25 \mathrm{mg}$ of the lyophilized enzyme was mixed in $10 \mathrm{mmol} /$ $\mathrm{L}$ of $p \mathrm{NPP}$ and $1 \mathrm{~mol} / \mathrm{L}$ of alcohol (ethanol, methanol, isopropanol, and isobutanol), and the final volume was adjusted to $1 \mathrm{~mL}$ with hexane. The reaction was incubated for $1 \mathrm{~h}$ at $60^{\circ} \mathrm{C}$ and $800 \mathrm{rpm}$, and then $1 \mathrm{~mL}$ of $\mathrm{NaOH}$ $(0.1 \mathrm{~mol} / \mathrm{L})$ was added to the reaction and the liberated $p$ NP was measured in a spectrophotometer at $410 \mathrm{~nm}$. The transesterification activity was defined as the amount of protein required to liberate $1 \mu \mathrm{mol}$ of $p \mathrm{NP}$ per minute under these condition. 
To evaluate the hydrolytic capacity of Pf_Est, titrations tests were carried out using different oils (olive, corn, soy, and waste cooking oil) as substrates. The assay was conducted according to Rabbani et al. [23] and Wang et al. [24] with some modifications. The enzymatic reactions, prepared in $50 \mathrm{~mL}$ Erlenmeyer flasks, were incubated on a reciprocal shaker at $100 \mathrm{rpm}$, at $80{ }^{\circ} \mathrm{C}$ for $30 \mathrm{~min}$. Each reaction contained $2.0 \mathrm{~mL}$ of oil in $11 \mathrm{~mL}$ of buffer (100 mmol/L Tris $\mathrm{HCl} \mathrm{pH} 8+$ Arabic Gum $0.1 \%$ $\mathrm{w} / \mathrm{v}+$ Triton X100 $0.4 \% \mathrm{w} / \mathrm{v})$ and $1 \mathrm{~mL}$ of purified enzyme $(0.94 \mathrm{mg} / \mathrm{mL})$. A blank reaction was performed without the enzyme. Reaction was stopped by adding $5 \mathrm{~mL}$ of ethanol. After the reaction, the released fatty acids were determined by titration with $\mathrm{NaOH} 0.25 \mathrm{~mol} / \mathrm{L}$ using bromothymol blue $(0.04 \%)$ as a $\mathrm{pH}$ indicator. One unit of enzyme activity was defined as $1.0 \mu \mathrm{mol}$ of fatty acid liberated per min.

\section{Results}

\section{Synthesis of Pf_Est}

In this study, we show a characterization of a hyperthermophilic esterase from Pyrococcus furiosus (Pf_Est). Pf_Est was synthesized based on the sequence deposited on NCBI (GenBank: AFN03900.1). Although this sequence was annotated as alpha-dextrin endo-1, 6-alpha-glucosidase, the BLAST and Pfam analysis of the region comprehending the amino acids 160-404, result on a CDD and a HMM, of an abhydrolase and esterase, respectively. $\alpha / \beta$ hydrolase fold protein class contains esterases, acetylcholinesterases, cutinases, carboxylesterases, and epoxide hydrolases [25]. Moreover, the sequence of the synthesized gene was submitted to I-Tasser analysis, and through the alignment of Pf_Est with other esterases, it was possible to found its catalytic triad (S126, E 181, and H 220), and also the consensus motif Gly-X-Ser-X-Gly, which catalytic serine is embedded (Figure S3). Besides, the biochemical and biophysical characterization of Pf_Est, showed on this manuscript reinforces the esterase activity of Pf_Est.

\section{Biochemical and Biophysical Characterization of Pf_Est}

The recombinant Pf_Est enzyme was expressed in the soluble fraction of $E$. coli BL21 (DE3) cells at $37^{\circ} \mathrm{C}$. The enzyme was purified using two chromatographic steps (Fig. 1a, b); and the purified enzyme presented a single band near $28 \mathrm{kDa}$ (Fig. 1c) in the SDS-PAGE analysis as expected. Moreover, the specific activities of purified enzyme for each purification steps are shown in Table 1.
As shown in Fig. 2a, Pf_Est presented activity over a broad $\mathrm{pH}$ range with maximum activity at $\mathrm{pH} 7.0$ with $\alpha$ naphthyl acetate, at $\mathrm{pH} 6.5$ with $\alpha$-naphthyl butyrate and at pH 8.0 with $p$ NPP. Pf_Est was able to retain more than $50 \%$ of its activity from $\mathrm{pH} 5.5$ to 10 with $\alpha$-naphthyl acetate and from $\mathrm{pH} 6.5$ to 8 with $\alpha$-naphthyl butyrate. The enzyme stability (Fig. 2c) showed that Pf_Est retain almost $100 \%$ of its activity at $\mathrm{pH} 7.5$ and 8.0 and more than $50 \%$ at $\mathrm{pH}$ 6.0-7.0.

For both $\alpha$-naphthyl substrates, the maximum activity was observed at $80{ }^{\circ} \mathrm{C}$, while for $p$ NPP the maximum activity was $5{ }^{\circ} \mathrm{C}$ degrees lower (Fig. 2b). Furthermore, the effect of temperature on activity of Pf_Est was examined by monitoring using $\alpha$-naphthyl acetate, $\alpha$-naphthyl butyrate, and $p$ NPP in the range from 55 to $100{ }^{\circ} \mathrm{C}$. The enzyme was able to retain about $50 \%$ of its activity at 50 and $85{ }^{\circ} \mathrm{C}$ for all substrates tested. Pf_Est was heatstable in all tested temperatures; after $48 \mathrm{~h}$ of incubation at $65,75,85$, and $120{ }^{\circ} \mathrm{C}$, the enzyme conserved $81,80,72$, and $42 \%$ of the initial activity, respectively (Fig. 2d).

Enzyme stability was tested in different water-miscible and -immiscible solvents in the proportions 5 and $50 \%$, $\mathrm{v} / \mathrm{v}$ (solvent/buffer). Pf_Est exhibited tolerance to low concentrations $(5 \% \mathrm{v} / \mathrm{v})$ of all solvents (Table 2). At higher concentrations, the enzyme was most active in the immiscible solvents and retained more than $50 \%$ of its activity in 2-propanol, isobutanol, and ethanol (Table 2).

The esterase kinetic parameters were calculated from the initial velocities using $12 p \mathrm{NPP}$ concentrations ranging from 0.05 to $6.0 \mathrm{mmol} / \mathrm{L}$. Pf_Est obeys the MichaelisMenten curve as expected [26], where the kinetics parameters were determined from the Michaelis-Menten adjustment of the curve shown in Fig. 2d. The Pf_Est presented a kcat of $1.6 \times 10^{-2} \mathrm{~s}^{-1}, \mathrm{Km}$ of $0.53 \mathrm{mM}$, and $V_{\max }$ of $6.5 \times 10^{-3} \mathrm{U}$, good indicators of an enzyme with great potential for use in biotechnological applications [27].

Jpre4 is a secondary protein structure prediction server, which provides predictions by the JNet algorithm with $82 \%$ accuracy. When submitting the Pf_Est sequence in the server (http://www.compbio.dundee.ac.uk/jpred/), a prediction of a protein was generated containing eight betasheets and seven alpha-helices.

Change in the secondary structure of Pf_Est was investigated by $\mathrm{CD}$ spectroscopy over the temperature range of $20-100^{\circ} \mathrm{C}$ (Fig. 2f). A positive band at 195-200 nm and a negative band at 210-220 nm were observed in the far-UV CD spectra, which is a typical profile observed for proteins rich in $\beta$-sheet structures $[28,29]$. According to the CD spectral data, Pf_Est maintains the secondary structure after incubation at $100^{\circ} \mathrm{C}$. Moreover, the enzyme was also able to preserve its structure after incubation at $120^{\circ} \mathrm{C}$ for $15 \mathrm{~min}$ (Fig. 2f). 
(a)

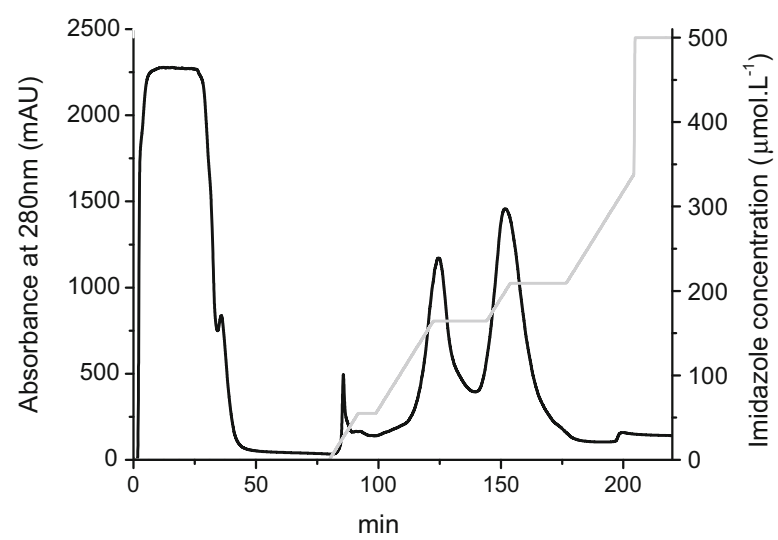

Fig. 1 a Elution profile of esterase in the $5 \mathrm{~mL}$ HiTrap Chelating HP column. Bound fractions were eluted using a nonlinear imidazole gradient (gray line) ranging from 5 to $500 \mathrm{mmol} / \mathrm{L}$ at $1 \mathrm{~mL} / \mathrm{min}$. b Size-exclusion chromatogram of esterase in a Superdex 200 10/300 (b)

(c)

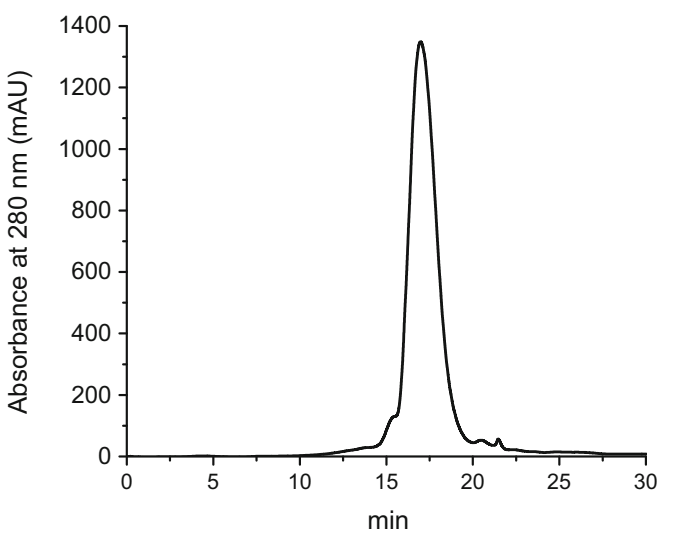

column in $20 \mathrm{mmol} / \mathrm{L}$ sodium phosphate buffer $\mathrm{pH} 7.5$ containing $100 \mathrm{mmol} / \mathrm{L} \mathrm{NaCl}$ at $0.5 \mathrm{~mL} / \mathrm{min}$. c SDS-PAGE analysis of esterase samples: 1 molecular weight marker (Thermo Scientific, USA), 2 purified esterase

Table 1 Specific activities of purified enzyme after each purification step

\begin{tabular}{lcccccc}
\hline Steps & Protein $(\mathrm{mg})$ & Activity $(\mathrm{U})^{\mathrm{a}}$ & Total activity $(\mathrm{U} / \mathrm{mL})^{\mathrm{a}}$ & ${\text { Specific activity }(\mathrm{U} / \mathrm{mg})^{\mathrm{a}}}^{\text {Fold purification }}$ & $\%$ Yield \\
\hline Lysate & 205.96 & $0.060 \pm 0.012$ & $11.967 \pm 2.447$ & $0.872 \pm 0.232$ & 1 & 100 \\
$\mathrm{Ni}^{2+}$ affinity & 12.02 & $0.024 \pm 0.002$ & $4.806 \pm 0.368$ & $4.743 \pm 0.157$ & 5.44 & 40 \\
Gel filtration & 10.22 & $0.019 \pm 0.001$ & $3.747 \pm 0.094$ & $5.654 \pm 0.568$ & 6.48 & 31 \\
\hline
\end{tabular}

a The activity was calculated using $p$ NPP assay

\section{Molecular Shape Envelope at Low Resolution and Structural Parameters}

To evaluate the overall shape and oligomeric state of Pf_Est, SAXS was performed at the optimum temperature and data were collected at three different protein concentrations: $0.5,1$, and $5 \mathrm{mg} / \mathrm{mL}$. The radius of gyration $\left(R_{\mathrm{g}}\right)$, obtained by Guinier approximations, presented similar values indicating the absence of interparticle correlation. Thus, further SAXS analysis was performed using data at the concentration of $5 \mathrm{mg} / \mathrm{mL}$.

A Porod constant of $1.10^{-3}$ was subtracted from the scattering pattern prior to the $p(r)$ analysis due to the high entropy of the system at $80{ }^{\circ} \mathrm{C}$. SAXS curve adjustments in reciprocal and real space were performed using the GNOM package [19] (Fig. 3a, b). The Guinier approximation (Fig. 3a-inset) respected the $q . R_{\mathrm{g}}<1.3$ limit [30], and the value $21.4 \AA$ is in good agreement with the radius of gyration $\left(R_{\mathrm{g}}\right)$ obtained from the $p(r), 19.72 \AA$ [19]. The crystallography model of the feruloyl esterase domain of the cellulosomal xylanase $\mathrm{z}$ from Clostridium thermocellum [31] (PDB id: 1JJF) presents a sequential identity of $27 \%$ compared to Pf_Est, where alignment was performed using blast pdb from the NCBI. The simulated SAXS curve and comparison with experimental data were conducted with the Crysol package [22] (Fig. 3a). The high-resolution data fit to the experimental data presented a $\chi^{2}$ value of 5.23. Molecular weight evaluation using SAXSmoW indicated that Pf_Est at $80{ }^{\circ} \mathrm{C}$ is present as a monomer in solution, with a discrepancy of $7.5 \%$ from the theoretical value $(28.55 \mathrm{kDa})$ which is expected due to the confidence interval of the method [20]. Dummy residues generated using the real space model correlate well with the crystallographic model (Fig. 3c). Good agreement is shown by the $\mathrm{p}(\mathrm{r})$ comparison (Fig. 3b). SAXS-derived parameters are shown in Table 3.

\section{Potential Biotechnological Application of Pf_Est}

The esterases are of industrial interest, since they have the capacity to catalyze hydrolytic as well as synthetic reactions. To promote synthetic catalysis, reactions are performed in the absence of water, instead of organic solvents or more recently, ionic liquids [32].

The transesterification activity of Pf_Est was investigated in the presence of four alcohols (methanol, ethanol, 2-propanol, and isobutanol) and $n$-hexane, using $p$ NPP as a 

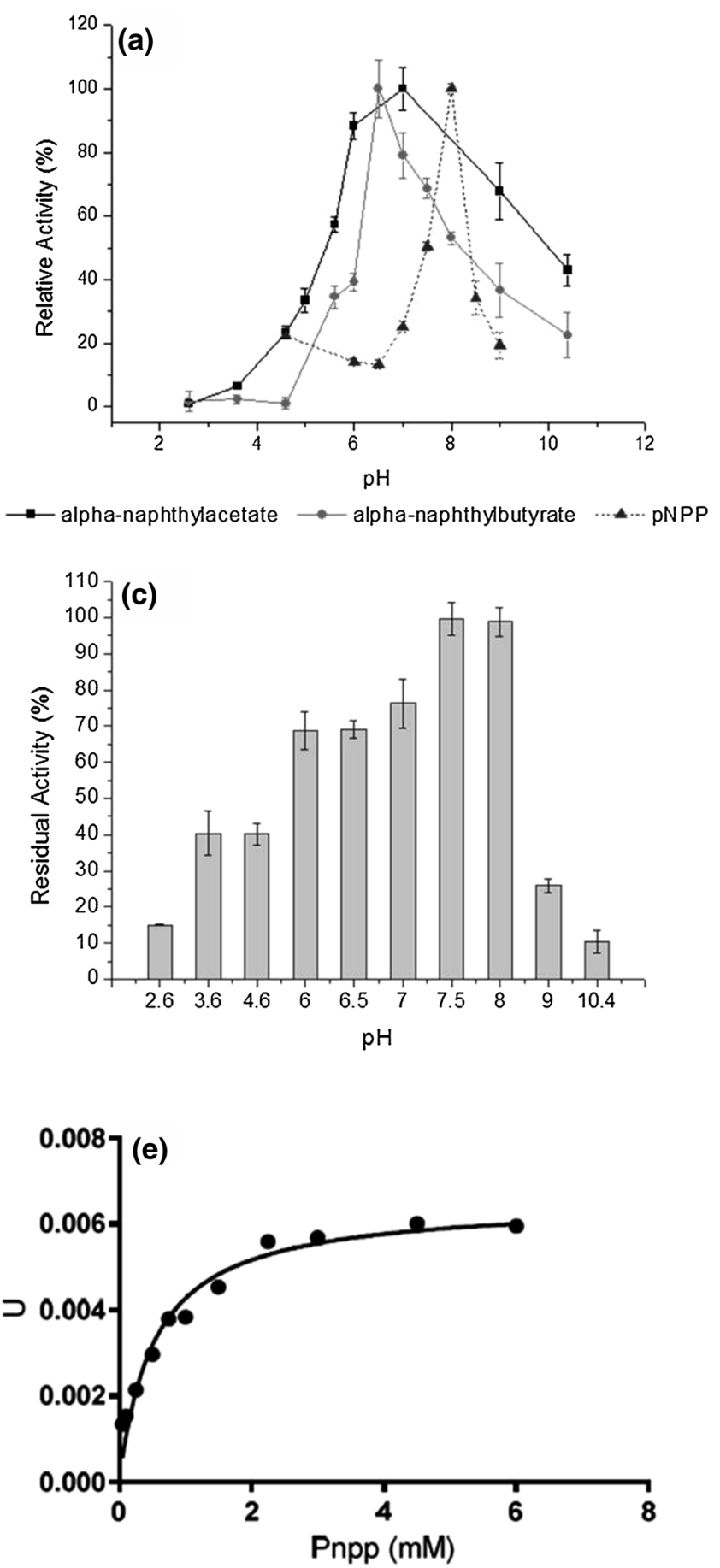

Fig. 2 Optimum pH (a) and temperature (b) and residual pH (c) and temperature (d) of esterase from $P$. furiosus. Michaelis-Menten adjustment made using the software Graph Pad Prism 6.0 (GraphPad Software) to calculate the kinetic parameters of $P$. furiosus esterase, where $p$ NPP was the substrate (e); Far-UV circular dichroism (CD)

substrate (Table 4). The best results were obtained in the transesterification activity with isobutanol while when methanol was used the Pf_Est presented the lowest transesterification activity.
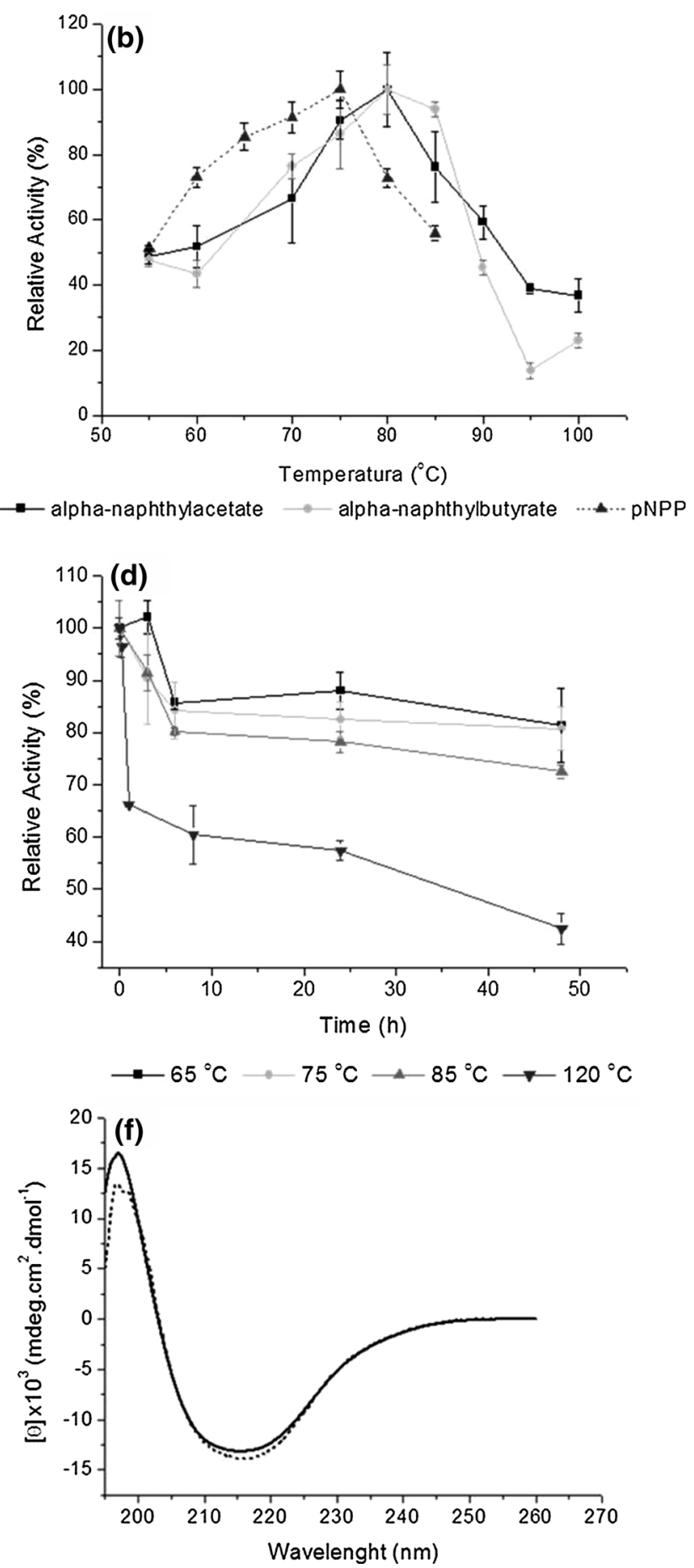

spectra of $P$. furiosus esterase. The experiment was carried out with $0.2 \mathrm{mg} / \mathrm{mL}$ of esterase in sodium phosphate buffer $\mathrm{pH} 7.5$ at $20^{\circ} \mathrm{C}$. The solid line is the $\mathrm{CD}$ spectra of the enzyme at $20{ }^{\circ} \mathrm{C}$ and the dashed line is the $\mathrm{CD}$ spectra after heating the enzyme to $120{ }^{\circ} \mathrm{C}$ for $15 \min (\mathbf{f})$

The hydrolytic activity of Pf_Est was tested against several oils and the highest activity was found toward olive oil $(6.2 \mathrm{U} / \mathrm{mg})$ followed by soy oil $(2.4 \mathrm{U} / \mathrm{mg})$, waste cooking oil $(1.8 \mathrm{U} / \mathrm{mg})$, and corn oil $(0.9 \mathrm{U} / \mathrm{mg})$. 


\section{Discussion}

Esterases often show broad substrate spectrum and are widely used as biocatalysts for the synthesis of important materials in pharmaceutical and chemical industries [33].

Table 2 Effects of water-miscible and -immiscible solvents on Pf_Est

\begin{tabular}{lcc}
\hline Solvents & \multicolumn{2}{c}{ Residual activity $\%$} \\
\cline { 2 - 3 } & $5 \%(\mathrm{v} / \mathrm{v})$ & $50 \%(\mathrm{v} / \mathrm{v})$ \\
\hline Isopropanol & 90.7 & 52.7 \\
Isobutanol & 118.3 & 63.9 \\
Methanol & 115.2 & 39.5 \\
Ethanol & 102.8 & 51.5 \\
Hexanol & 99.8 & 111.2 \\
Dichloromethane & 213.0 & 369.0 \\
\hline
\end{tabular}

(a)

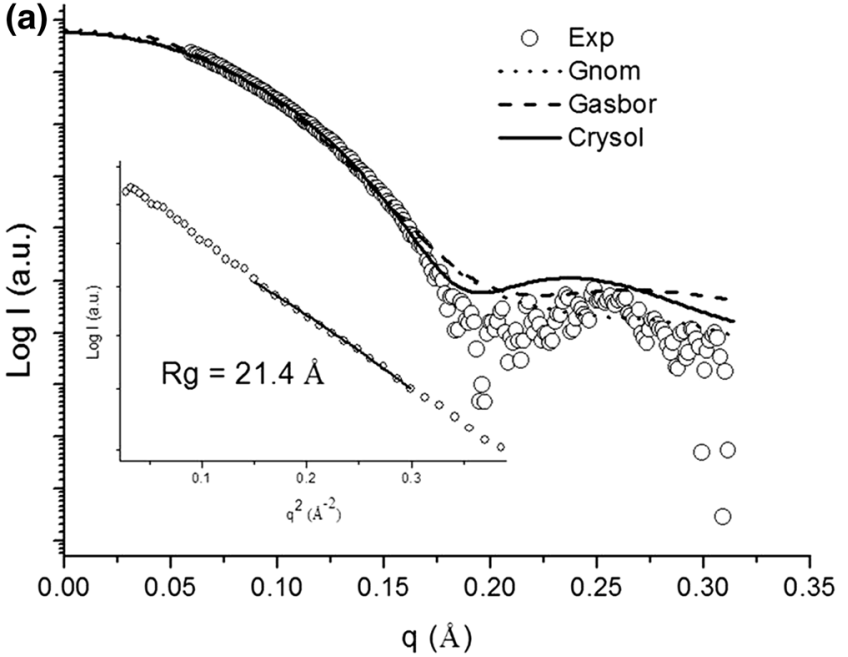

In this study, the gene encoding a hyperthermophilic esterase from Pyrococcus furiosus was synthesized, subcloned in an expression vector, expressed in a mesophilic host, purified, and biochemically and biophysically characterized.

Pf_Est presented optimum $\mathrm{pH}$ activity at $6.5-7.0$ in naphthol-derivate substrates, which is slightly lower than the optimum $\mathrm{pH}$ (7.5) reported earlier for esterases from Brevibacterium linens ATCC 9174, Thermus thermophilus HB27, and Geobacillus sp. TF17 [34-36]. The optimum temperature for Pf_Est activity was $80^{\circ} \mathrm{C}$ in $\alpha$-naphthyl acetate (and butyrate) and $75{ }^{\circ} \mathrm{C}$ in $p$ NPP. Moreover, the half-life of this enzyme at $120{ }^{\circ} \mathrm{C}$ is approximately $34 \mathrm{~h}$ using $p$ NPP as substrate. Previous studies show the Pf_Est half-life of $34 \mathrm{~h}$ at $100{ }^{\circ} \mathrm{C}, 6 \mathrm{~h}$ at $110{ }^{\circ} \mathrm{C}, 2 \mathrm{~h}$ at $120^{\circ} \mathrm{C}$, and $50 \mathrm{~min}$ at $126^{\circ} \mathrm{C}$ [11]. The stability present by Pf_Est is higher than the stability of others enzymes from $P$. furiosus previously described in the literature [37, 38].

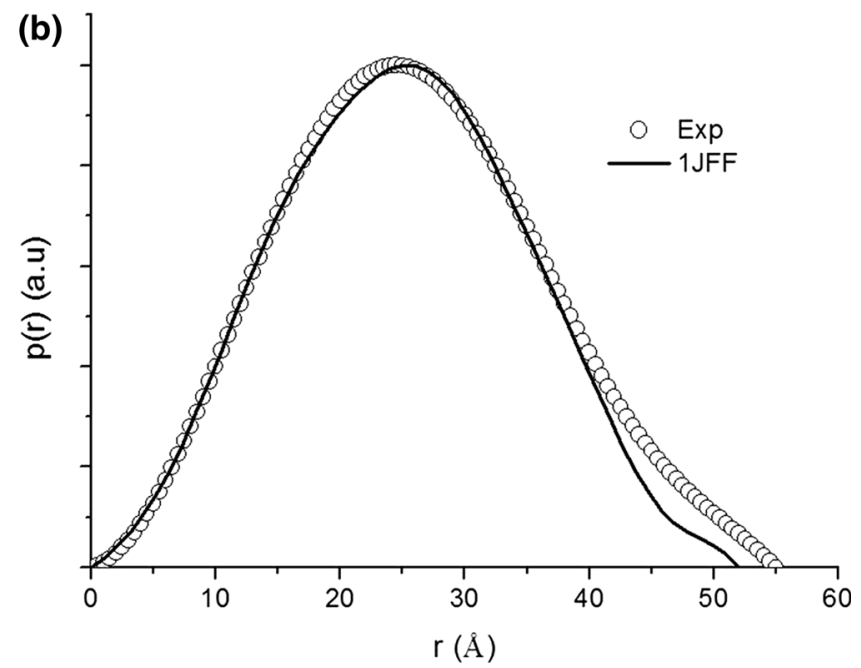

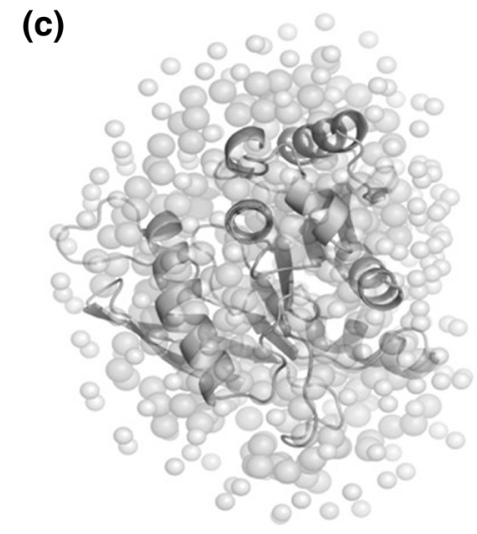

Fig. 3 Experimental SAXS curve of the hyperthermophilic esterase from $P$. furiosus and fitting procedures. Inset Guinier's approximation (a). $p(r)$ comparison of the experimental data and the crystallographic simulated scattering (b), Superposition of the crystallographic model for the feruloyl esterase domain of the cellulosomal xylanase $\mathrm{z}$ of
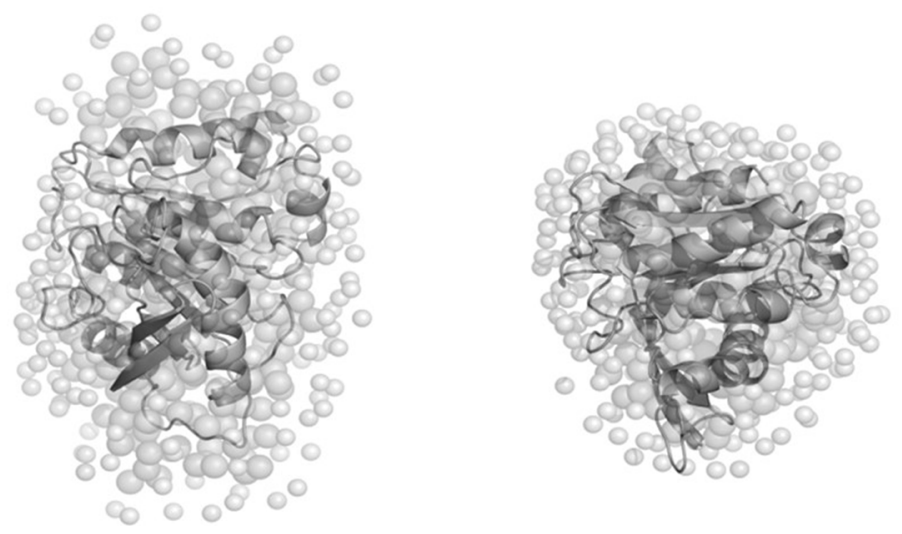

Clostridium thermocellum [31] (PDB id: 1JJF) with the lowresolution model generated by Gasbor. The center and right models were rotated $90^{\circ}$ around the $y$ axis and $90^{\circ}$ around the $x$ axis from the orientation shown on the left panel (c) 
Table 3 SAXS structural parameters of hyperthermophilic esterase from P. furiosus

\begin{tabular}{|c|c|c|c|}
\hline Parameters & Experimental $(5 \mathrm{mg} / \mathrm{mL})$ & DR model & Crystallographic model \\
\hline$R_{\mathrm{g}}(\mathrm{A})($ Guinier $)$ & 21.4 & - & - \\
\hline$R_{\mathrm{g}}(\AA)$ & 19.72 & - & 16.45 \\
\hline$D_{\max }(\AA)$ & 55.0 & - & 52.27 \\
\hline SAXS resolution $(\AA)$ & 20.02 & 20.02 & - \\
\hline Molecular weight (kDa) & 30.7 & - & - \\
\hline$\chi^{2}$ & - & 3.62 & 5.23 \\
\hline
\end{tabular}

Table 4 Transesterification activity of $P$. furiosus esterase

\begin{tabular}{ll}
\hline Alcohol & $\begin{array}{l}\text { Transesterification activity } \\
\left(\times 10^{-2} \mu \mathrm{mol} / \mathrm{min} \cdot \mathrm{mg}\right)\end{array}$ \\
\hline Methanol & $0.21 \pm 0.01$ \\
Ethanol & $0.79 \pm 0.09$ \\
2-propanol & $0.78 \pm 0.07$ \\
Isobutanol & $2.69 \pm 0.14$ \\
\hline
\end{tabular}

Pf_Est presented the same optimum temperature as the archaeon Sulfolobus solfataricus P1 [39], higher than Bacillus licheniformis S-86 $\left(60{ }^{\circ} \mathrm{C}\right)$ and Fervidobacterium nodosum Rt17-B1 $\left(75^{\circ} \mathrm{C}\right)[40,41]$. On the other hand, the optimum temperature of Pf_Est is lower than that from Thermotoga maritima $\left(95^{\circ} \mathrm{C}\right)$, although it is important to highlight that in spite of the lower optimum temperature, Pf_Est is more stable than T. maritima esterase EstD [42].

In addition, thermal denaturation of Pf_Est was accompanied by the measurement of the change in ellipticity at $221 \mathrm{~nm}$ over the temperature range of $20-100{ }^{\circ} \mathrm{C}$, showing that Pf_Est did not lose its secondary structure over this temperature range. These data reinforce the higher thermostability of Pf_Est when comparing to others previously described in the literature [36, 39, 42].

The kcat $/ \mathrm{km}$ ratio of Pf_Est $\left(3.02 \times 10^{-2}(\mathrm{mmol} / \mathrm{L}) / \mathrm{s}\right)$ using $p$ NPP as substrate was similar to the ratio presented by lipase (189E r03Lip) from Geobacillus sp. $\left(2.90 \times 10^{-2}(\mathrm{mmol} / \mathrm{L}) / \mathrm{s}\right)$ and higher than the bovine serum albumin at $70{ }^{\circ} \mathrm{C}\left(1.75 \times 10^{-2}(\mathrm{mmol} / \mathrm{L}) / \mathrm{s}\right)$ [43] The kinetics parameters presented by Pf_Est indicates that it is an enzyme with great potential for use in biotechnological applications, especially in application at high temperatures.

Pf_Est showed a good stability toward solvents, showing high tolerance to immiscible solvents at the highest concentration $(50 \% \mathrm{v} / \mathrm{v})$. This is an important characteristic once immiscible organic solvents are the preferred as reaction medium, once they provide greatest solubility of lipases target substrates [44]. On the other hand, miscible solvents are commonly used as substrates in esterification reactions mediated by lipases [45]. Thus, the stability in front of miscible solvents obtained by Pf_Est is also interesting for biotechnological applications.
The prediction of the secondary structure of Pf_Est performed using Jpre4 was in accordance with the canonical structure of esterases which consists of a highly twisted, 8-11-stranded beta-sheet in which most strands are parallel and this sheet is flanked on both sides by alphahelices [46]. Guo et al. [47] observed the same pattern as it was observed in Pf_Est for a Mycobacterium tuberculosis esterase; however, esterases generally present a CD profile with predominance of alpha-helices [48-51], probably due to the presence of these structures in the external portion of the proteins. Moreover, SAXS analysis revealed a monomeric shape of Pf_Est in solution at its optimum temperature $\left(80^{\circ} \mathrm{C}\right)$. Collectively, CD and SAXS data reinforce the fact that the hyperthermophilic esterase from $P$. furiosus was successfully expressed by the mesophilic host (E. coli) preserving its correct fold and high stability.

The transesterifications values presented by the $P$. furiosus esterase for methanol, ethanol, and 2-propanol were lower than those obtained by [14] for wild and mutants lipases of Geobacillus sp. NTU03. The lowest transesterification value of Pf_Est was found when using methanol, the same pattern was observed lipases from Geobacillus sp. and Candida antarctica $[13,28]$. On the other hand, the highest transesterification value of Pf_Est was found when using isobutanol as the acyl acceptor (more than three times higher than for the others alcohols). This is consistent with the general agreement that water-miscible polar solvents can strip off the water layer that forms around many proteins, which is essential for activity [52]. In contrast, nonpolar solvents may protect the microenvironment of enzymes, thereby preventing loss of the water layer.

The hydrolytic activity of $P$. furiosus esterase was determined and the enzyme was able to hydrolyze all lipids tested. The highest hydrolysis degree occurred using olive oil (6.2 U/mg), similar to Dharmsthiti et al. [53] (4.8 U/ $\mathrm{mg}$ ) indicating good affinity for long-chain unsaturated fatty acids such as oleic acid, C18:1 cis-9 which is the predominant fatty acid in olive oil [54]. Soy oil (2.4 U/mg), waste cooking oil $(1.8 \mathrm{U} / \mathrm{mg})$, and corn oil $(0.9 \mathrm{U} / \mathrm{mg})$ were also hydrolyzed, which indicates Pf_Est hydrolysis ability against a broad spectrum of lipids, which can be interesting for detergent formulation increasing their effectiveness on different types of dirt [15]. 
Therefore, the extremely thermostable esterase described here presents potential to be used in a wide range of biotechnological applications such as synthesis and improvement of flavor esters and aroma in the food industry, modification of triglycerides in the oil industry, resolution of racemic mixtures for synthesis of pure chemicals in the pharmaceutical industry, as well as in the insecticides degradation and reduction of toxic compounds of plastic [8]. Thus, it refers to enzymes with great relevance and biotechnological potential, and therefore, the characterization is indispensable for effective and specific application.

In conclusion, this study describes the successful purification and characterization in terms of both functional and structural aspects of a hyper thermostable esterase from Pyrococcus furiosus, in addition to determination of the low-resolution structure of this enzyme by SAXS. Our findings provide biochemical and structural basis for further studies of esterases, indicating that Pf_Est may be suitable for applications in the chemical, food, and pharmaceutical industries.

Acknowledgments The authors would like to thank the Brazilian National Council for Scientific Research (CNPq) for financial support (310186/2014-5, 442333/2014-5, 313749/2014-0, and 140796/2013$4)$.

\section{References}

1. Arpigny, J. L., \& Jaeger, K. E. (1999). Bacterial lipolytic enzymes: classification and properties. The Biochemical Journal, 343(Pt 1), 177-183.

2. Anbu, P., Gopinath, S. C. B., Cihan, A. C., \& Chaulagain, B. P. (2013). Microbial enzymes and their applications in industries and medicine. BioMed Research International, 2013, 2-4.

3. Jaeger, K. E., \& Reetz, M. T. (1998). Microbial lipases form versatile tools for biotechnology. Trends in Biotechnology, 16(9), 396-403.

4. Jaeger, K. E., Schneidinger, B., Rosenau, F., Werner, M., Lang, D., Dijkstra, B. W., et al. (1997). Bacterial lipases for biotechnological applications. Journal of Molecular Catalysis B Enzymatic, 3(1-4), 3-12.

5. Ray, A. (2012). Application of lipase in industry. Asian Journal of Pharmaceutical Technology, 2(2), 33-37.

6. Kim, J., Deng, L., Hong, E., \& Ryu, Y. (2015). Cloning and characterization of a novel thermostable esterase from Bacillus gelatini KACC 12197. Protein Expression and Purification, 116, 90-97.

7. Kawamoto, T., Sonomoto, K., \& Tanaka, A. (1987). Esterification in organic solvents: selection of hydrolases and effects of reaction conditions. Biocatalysis and Biotransformation, 1(2), 137-145.

8. Panda, T., \& Gowrishankar, B. S. (2005). Production and applications of esterases. Applied Microbiology and Biotechnology, 67(2), 160-169.

9. Cowan, D. (1992). Enzymes from thermophilic archaebacteria: current and future applications in biotechnology. Biochemical Society Symposia, 58, 149-169.
10. Fiala, G., \& Stetter, K. O. (1986). Pyrococcus furiosus; sp. nov. represents a novel genus of marine heterotrophic archaebacteria growing optimally at $100{ }^{\circ} \mathrm{C}$. Archives of Microbiology, 145(1), $56-61$.

11. Ikeda, M., \& Clark, D. S. (1998). Molecular cloning of extremely thermostable esterase gene from hyperthermophilic archaeon Pyrococcus furiosus in Escherichia coli. Biotechnology and Bioengineering, 57(5), 624-629.

12. Beaucage, S. L., \& Iyer, R. P. (1992). Advances in the synthesis of oligonucleotides by the phosphoramidite approach. Tetrahedron, 48(12), 2223-2311.

13. Damásio, A. R. L., Braga, C. M. P., Brenelli, L. B., Citadini, A. P., Mandelli, F., Cota, J., et al. (2013). Biomass-to-bioproducts application of feruloyl esterase from Aspergillus clavatus. Applied Microbiology and Biotechnology, 97(15), 6759-6767.

14. Shih, T.-W., \& Pan, T.-M. (2011). Substitution of Asp189 residue alters the activity and thermostability of Geobacillus sp. NTU 03 lipase. Biotechnology Letters, 33(9), 1841-1846.

15. Sande, D., Souza, L. T. A., Oliveira, J. S., Santoro, M. M., Lacerda, I. C. A., Colen, G., et al. (2015). Colletotrichum gloeosporioides lipase: characterization and use in hydrolysis and esterifications. African Journal of Microbiology Research, 9(19), 1322-1330.

16. Mandelli, F., Franco Cairo, J. P. L., Citadini, A. P. S., Büchli, F., Alvarez, T. M., Oliveira, R. J., et al. (2013). The characterization of a thermostable and cambialistic superoxide dismutase from thermus filiformis. Letters in Applied Microbiology, 57(1), $40-46$.

17. Hammersley, A. P. (1997). FIT2D: an introduction and overview. ESRF Internal Report ESRF97HA02.

18. Alvarez, T. M., Goldbeck, R., dos Santos, C. R., Paixão, D. A. A., Gonçalves, T. A., Franco Cairo, J. P. L., et al. (2013). Development and biotechnological application of a novel endoxylanase family GH10 identified from sugarcane soil metagenome. PLoS One, 8(7), e70014.

19. Svergun, D. I. (1992). Determination of the regularization parameter in indirect-transform methods using perceptual criteria. Journal of Applied Crystallography, 25(pt 4), 495-503.

20. Fischer, H., de Oliveira Neto, M., Napolitano, H. B., Polikarpov, I., \& Craievich, A. F. (2009). Determination of the molecular weight of proteins in solution from a single small-angle X-ray scattering measurement on a relative scale. Journal of Applied Crystallography, 43(1), 101-109.

21. Kozin, M. B., \& Svergun, D. I. (2001). Automated matching of high- and low-resolution structural models. Journal of Applied Crystallography, 34(1), 33-41.

22. Svergun, D., Barberato, C., \& Koch, M. H. (1995). CRYSOL-a program to evaluate $\mathrm{X}$-ray solution scattering of biological macromolecules from atomic coordinates. Journal of Applied Crystallography, 28(6), 768-773.

23. Rabbani, M., Bagherinejad, M. R., Sadeghi, H. M., Shariat, Z. S., Etemadifar, Z., Moazen, F., et al. (2013). Isolation and characterization of novel thermophilic lipase-secreting bacteria. Brazilian Journal of Microbiology, 44(4), 1113-1119.

24. Wang, L., Mavisakalyan, V., Tillier, E. R. M., Clark, G. W., Savchenko, A. V., Yakunin, A. F., et al. (2010). Mining bacterial genomes for novel arylesterase activity. Microbial Biotechnology, 3(6), 677-690.

25. Contesini, F. J., Calzado, F., Madeira, J. V., Rubio, M. V., Zubieta, M. P., de Melo, R. R., et al. (2016). Aspergillus lipases: Biotechnological and industrial application. In J. M. Mérillon \& K. G. Ramawat (Eds.), Reference series in phytochemistry: Fungal metabolites (pp. 1-28). Cham, Switzerland: Springer International Publishing. 
26. Bornscheuer, U. T. (2002). Microbial carboxyl esterases: classification, properties and application in biocatalysis. FEMS Microbiology Reviews, 26(1), 73-81.

27. Fullbrook, P. (1996). Practical applied kinetics, industrial enzymology (2nd ed.). New York: Stockholm Press.

28. Kelly, S., \& Price, N. (2000). The use of circular dichroism in the investigation of protein structure and function. Current Protein and Peptide Science, 1(4), 349-384.

29. Greenfield, N. J. (2006). Using circular dichroism spectra to estimate protein secondary structure. Nature Protocols, 1(6), 2876-2890.

30. Guinier, A., \& Fournet, G. (1955). Small angle scattering of X-rays. Journal of Polymer Science, 1, 268.

31. Schubot, F. D., Kataeva, I. A., Blum, D. L., Shah, A. K., Ljungdahl, L. G., Rose, J. P., et al. (2001). Structural basis for the substrate specificity of the feruloyl esterase domain of the cellulosomal xylanase $\mathrm{Z}$ from Clostridium thermocellum. Biochemistry, 40(42), 12524-12532.

32. Carvalho, C. M. L., \& Cabral, J. M. S. (2000). Reverse micelles as reaction media for lipases. Biochimie, 82, 1063-1085.

33. Chen, Q., Luan, Z.-J., Cheng, X., \& Xu, J.-H. (2015). Molecular dynamics investigation of the substrate binding mechanism in carboxylesterase. Biochemistry, 54(9), 1841-1848.

34. Rattray, F. P., \& Fox, P. F. (1997). Purification and characterisation of an intracellular aminopeptidase from Brevibacterium linens ATCC 9174. Lait.

35. Fuciños, P., Atanes, E., López-López, O., Esperanza Cerdán, M., Isabel González-Siso, M., Pastrana, L., et al. (2011). Production and characterization of two $\mathrm{N}$-terminal truncated esterases from Thermus thermophilus HB27 in a mesophilic yeast: effect of $\mathrm{N}$-terminus in thermal activity and stability. Protein Expression and Purification, 78(2), 120-130.

36. Ayna, Ç., Kolcuoğlu, Y., Öz, F., Colak, A., \& Ertunga, N. S. (2013). Purification and characterization of a $\mathrm{pH}$ and heat stable esterase from Geobacillus sp. TF17. TurkJBiochem, 4685, 329-336.

37. Almeida, R., Alqueres, S., Larentis, A., Rossle, S., Cardoso, A., Almeida, W., et al. (2006). Cloning, expression, partial characterization and structural modeling of a novel esterase from $P y$ rococcus furiosus. Enzyme and Microbial Technology, 39(5), $1128-1136$

38. Chandrayan, S. K., Dhaunta, N., \& Guptasarma, P. (2008). Expression, purification, refolding and characterization of a putative lysophospholipase from Pyrococcus furiosus: retention of structure and lipase/esterase activity in the presence of watermiscible organic solvents at high temperatures. Protein Expression and Purification, 59(2), 327-333.

39. Nam, J.-K., Park, Y.-J., \& Lee, H.-B. (2013). Cloning, expression, purification, and characterization of a thermostable esterase from the archaeon Sulfolobus solfataricus P1. Journal of Molecular Catalysis B: Enzymatic, 94, 95-103.

40. Torres, S., Baigorí, M. D., Swathy, S. L., Pandey, A., \& Castro, G. R. (2009). Enzymatic synthesis of banana flavour (isoamyl acetate) by Bacillus licheniformis S-86 esterase. Food Research International, 42(4), 454-460.

41. Yu, S., Zheng, B., Zhao, X., \& Feng, Y. (2010). Gene cloning and characterization of a novel thermophilic esterase from
Fervidobacterium nodosum Rt17-B1. Acta Biochimica et Biophysica Sinica, 42(4), 288-295.

42. Levisson, M., van der Oost, J., \& Kengen, S. W. M. (2007). Characterization and structural modeling of a new type of thermostable esterase from Thermotoga maritima. The FEBS Journal, 274(11), 2832-2842.

43. Córdova, J., Ryan, J. D., Boonyaratanakornkit, B. B., \& Clark, D. S. (2008). Esterase activity of bovine serum albumin up to $160{ }^{\circ} \mathrm{C}$ : a new benchmark for biocatalysis. Enzyme and Microbial Technology, 42(3), 278-283.

44. Tamalampudi, S., Hama, S., Tanino, T., Talukder, M. R., Kondo, A., \& Fukuda, H. (2007). Immobilized recombinant Aspergillus oryzae expressing heterologous lipase: an efficient whole-cell biocatalyst for enantioselective transesterification in non-aqueous medium. Journal of Molecular Catalysis B: Enzymatic, 48(1-2), 33-37.

45. Mustranta, A., Forssell, P., \& Poutanen, K. (1993). Applications of immobilized lipases to transesterification and esterification reactions in nonaqueous systems. Enzyme and Microbial Technology, 15(2), 133-139.

46. Marchot, P., \& Chatonnet, A. (2012). Enzymatic activity and protein interactions in alpha/beta hydrolase fold proteins: moonlighting versus promiscuity. Protein and Peptide Letters, $19(2), 132-143$.

47. Guo, J., Zheng, X., Xu, L., Liu, Z., Xu, K., Li, S., et al. (2010). Characterization of a novel esterase Rv0045c from Mycobacterium tuberculosis. PLoS One, 5(10), e13143.

48. Rhee, J. K., Kim, D. Y., Ahn, D. G., Yun, J. H., Jang, S. H., Shin, H. C., et al. (2006). Analysis of the thermostability determinants of hyperthermophilic esterase EstE1 based on its predicted threedimensional structure. Applied and Environmental Microbiology, 72(4), 3021-3025.

49. Dang, G., Chen, L., Li, Z., Deng, X., Cui, Y., Cao, J., et al. (2015). Expression, purification and characterisation of secreted esterase Rv2525c from Mycobacterium tuberculosis. Applied Biochemistry and Biotechnology, 176(1), 1-12.

50. Benavente, R., Esteban-Torres, M., Acebrón, I., De Las Rivas, B., Muñoz, R., Álvarez, Y., et al. (2013). Structure, biochemical characterization and analysis of the pleomorphism of carboxylesterase Cest-2923 from Lactobacillus plantarum WCFS1. FEBS Journal, 280(24), 6658-6671.

51. Li, P. Y., Ji, P., Li, C. Y., Zhang, Y., Wang, G. L., Zhang, X. Y., et al. (2014). Structural basis for dimerization and catalysis of a novel sterase from the GTSAG motif subfamily of the bacterial hormone-sensitive lipase family. Journal of Biological Chemistry, 289(27), 19031-19041.

52. Gupta, M. N. (1992). Enzyme function in organic solvents. European Journal of Biochemistry/FEBS, 203(1992), 25-32.

53. Dharmsthiti, S., \& Luchai, S. (1999). Production, purification and characterization of thermophilic lipase from Bacillus sp. THL027. FEMS Microbiology Letters, 179(2), 241-246.

54. Pastore, G. M., Costa, V. D., \& Koblitz, M. G. (2003). Production, partial purification and biochemical characterization of a novell Rhizopus sp. strain lipase. Food Science and Technology (Campinas), 23(2), 135-140. 